\title{
Trends in physicians' giving advice to stop smoking, United States, 1974-87
}

\author{
Elizabeth Gilpin, John Pierce, Jerry Goodman, Gary Giovino, Charles Berry, \\ David Burns
}

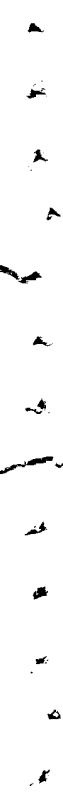

Population Studies for Cancer

Prevention, Cancer Center, University of California, San Diego, La Jolla, California 92093-0901, USA E Gilpin

J Pierce

J Goodman

Office on Smoking

and Health, National

Center for Chronic

Disease Prevention

and Health

Promotion, Centers

for Disease Control,

Atlanta, Georgia

30333, USA

G Giovino

Department of

Community and

Family Medicine,

University of

California Medical

Center, San Diego

California 92103, USA

C Berry

Division of

Pulmonary and

Critical Care

Medicine, University

of California Medical

Center, San Diego,

California 92103, USA

D Burns

Correspondence to: $\mathrm{Dr}$ Pierce.

\begin{abstract}
Objective To assess patients' reported rate of receiving advice from a physician to stop smoking from 1974 to 1987 and identify any differences among demographic subgroups.

Design Analysis of demographic factors and reported advice to stop smoking in current smokers identified from the 1974, 1976, and 1987 national health interview surveys and the 1986 adult use of tobacco survey.
\end{abstract}

Setting Large population surveys, United States.

Subjects 40466 subjects aged $\geqslant 20$ who had smoked 100 cigarettes in their lifetime.

Main outcome measures Likelihood of an ever-smoker reporting advice to stop smoking in 1974-6 and 1986-7 by age, sex, race, and education.

Results The percentage of smokers who reported receiving advice increased from $26.4 \%$ in 1976 to $50.9 \%$ in 1987 . The reported rate of receiving advice was 1.8 times higher in 1986-7 compared with 1974-6. In both periods the likelihood of reporting advice from a physician was highest for women, older people, more highly educated people, and white people. In both periods young men reported receiving advice to stop smoking at a much lower rate than did men who were older or women of any age. However, half of all current smokers in 1987 could not recall having been advised by a physician to stop smoking.

Conclusion As advice from physicians to stop smoking is effective, physicians must heed the recent call by the American Medical Association that they advise all their smoking patients to stop at every contact.

\section{Introduction}

Convincing smokers to stop smoking has been a major public health goal in the United States, the United Kingdom, and other countries for more than 25 years. ${ }^{12}$ Efforts have been somewhat successful: the number of former smokers in the United States is increasing by approximately 1 million each year. ${ }^{3}$ However, approximately 50 million people in the United States are still smokers, so we are still far from the goal of a smoke free society. ${ }^{4}$ The public health goals in the United States for the year 2000 are to more than double the current rate of stopping and decrease the prevalence of smoking to $15 \%{ }^{5}$

Achieving these public health goals requires increasing the use of interventions that help smokers stop smoking. One intervention with considerable potential to effect change is advice from physicians. ${ }^{6-8}$ Approximately $70 \%$ of adults visit a physician each year. ${ }^{910} \mathrm{~A}$ brief (1-3 minute) intervention by the physician during such a visit has been associated with a long term rate of stopping smoking of between $5 \%$ and $10 \% \cdot{ }^{11-18}$ On the basis of these success rates, if each of 200000 physicians spent a brief time counselling each patient who smokes the proportion of smokers who successfully stop smoking each year might double. ${ }^{19}$

Surveys of physicians indicate that they are interested in helping their patients to stop smoking and that a considerable majority $(52 \%$ to $97 \%)$ think that they have incorporated giving advice about stopping smoking routinely into their practice. ${ }^{20-27}$ However, the perceptions of the patients and the physicians about the advice given might differ. In this paper we present data on patients' reporting of advice given by physicians over time and identify demographic subgroups that are more or less likely to report receiving such advice.

\section{Subjects and methods}

STUDY POPULATIONS

Information about physicians' advice to stop smoking was collected in national health interview surveys (1974 $(\mathrm{n}=25565), 1976$ $(\mathrm{n}=23088)$, and $\left.1987(\mathrm{n}=22080)^{2829}\right)$ and the 1986 adult use of tobacco survey $(n=$ 13031). ${ }^{3031}$ The three national health interview surveys were mainly household personal interviews with response rates exceeding $85 \%$, and the adult use of tobacco survey was a telephone survey (each number dialled at random) with a response rate of $74 \%$.

This study included 40466 ever-smokers aged 20 years or older who had indicated whether they had received advice to stop smoking from a physician.

\section{MEASURES}

In each survey year ever-smokers were defined as those who had smoked over 100 cigarettes in their lifetime. Current smokers were defined as those who answered "yes" to the question, 
"Do you smoke cigarettes now?" In the 1986 and 1987 surveys only the date of smoking cessation was available.

In the 1974 and 1976 surveys respondents were asked, "Have you ever been advised by a doctor to quit smoking?" In the 1986 survey, respondents were asked, "Did any doctor ever advise you to quit smoking?" Finally, in the 1987 survey the question was, "Has a doctor ever advised you to quit smoking?"

Demographic variables examined included age, sex, race, education, and marital status. Age (at the respondent's last birthday) was coded as an ordinal variable with the following four values: $20-29$ years, 30-44 years, 45-64 years, and 65 years and more. Educational attainment was divided into four ordinal levels according to the number of years of completed schooling: less than 12 years (not a high school graduate), 12 years (high school graduate), 13-15 years (some education at college), and 16 years or more (college graduate). Race was coded as a three category nominal variable indicating white, black, or other.

\section{ANALYSES}

All analyses used unweighted data because the data needed to be grouped across study designs. Separate analyses of changes in reported advice with time were performed in three groups: (a) former smokers, (b) current smokers, and (c) both current smokers and former smokers for whom we knew the date of smoking cessation (from survey years 1986 and 1987). Advice rates over survey years and the time since former smokers had smoked were compared by using the $\chi$ test for trend. ${ }^{32}$

To examine the relation of demographic factors to the reported rates of advice received among current smokers two groups were used: one group from the early period (1974 and 1976) and one group from the more recent period (1986 and 1987). A log linear analysis was used to examine the likelihood of reporting advice received with respect to time period, sex, age, race, and educational level. ${ }^{33}$ The main effects and interactions of demographic factors with time period and selected significant higher order interactions were included in the model.

\section{Results}

INCREASE IN REPORTED ADVICE WITH TIME

The overall percentages of former and current smokers who had been advised to stop smoking as reported in each survey year increased between the mid-1970s and the late 1980s, especially when the last two survey years were compared with the first two and in current smokers $\left(\mathrm{p}<10^{-8}\right)$ (figure 1 ). In 1974, 26.4\% of current smokers reported receiving advice to stop smoking, and this percentage increased to $50.9 \%$ in 1987 . The temporal differences among former smokers depended on the year in which the smoker stop smoking. The effect of this relation is seen in the 1986 and 1987 data (figure 2): smokers who had stopped more than 10 years before the survey reported levels of advice similar to the levels shown in figure 1 for current smokers in 1974. Reporting of advice increased with the recency of stopping smoking: those who had stopped within the past year reported nearly the same level of advice as did current smokers.

DEMOGRAPHIC SUBGROUPS AND RELATION TO RATES OF REPORTED ADVICE WITH TIME

Overall, current smokers in the 1986 and 1987 surveys reported receiving advice 1.8 times more frequently than did those in the 1974 and 1976 surveys (table). In both periods women reported receiving advice more frequently than did men, but the increase over time for both sexes was nearly the same. Although in both survey periods the rate of reported advice increased with age, this increase tended to even out in the later time period because the increase was greater for the younger age groups. Black subjects reported receiving advice less frequently than did white subjects, but they showed a slightly higher increase over time than did white subjects. People of other racesfor example, Asian, Native American-showed the largest increase. Smokers with more than a high school education reported receiving advice more often than those with a high school education or less, and all educational levels showed about the same degree of increase with time.

In the log linear analysis all the main effects (sex, age, race, and education) were significant, but none of the interactions of these factors and time period proved significant; this finding indicated that the pattern of advice in the later time period was substantially the same as that in the earlier period. In a preliminary analysis within each time period and in the final analysis significant interaction was shown between the rates of advice given and sex and age. In both periods the percentage of younger men who reported receiving advice to stop smoking was much lower than the percentage of younger women who reported receiving such advice; older men reported receiving advice slightly more frequently than did older women (figure 3 ). When the increases in advice over time were compared women aged 20 to 29 years showed a $2 \cdot 3$-fold increase, but in the other groups the factor increase ranged from 1.7 to 1.9 .

\section{Discussion}

In the period from 1986 to $1987,80 \%$ more current smokers reported that a doctor had advised them to stop smoking than had reported such advice in the mid-1970s. This increase follows the trend over time noted earlier. ${ }^{4}$ For the 1964 adult use of tobacco survey $15 \%$ of current smokers reported receiving advice. ${ }^{34}$ By 1966 the percentage had increased to $16.9 \%{ }^{34}$; by 1970 it had climbed to $21.8 \%,{ }^{35}$ and by the mid-1980s it had reached $50 \%$. A survey of 5875 adults in Michigan conducted in the early 1980 s yielded a $44 \%$ rate of reported advice, ${ }^{36}$ which is between the $27.3 \%$ rate for the mid- $1970 \mathrm{~s}^{37}$ $\because$

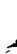

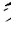

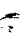

$+$

$+$

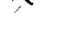

t.

$\div$

$\rightarrow$

$-$

$\therefore$

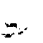

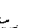

$\therefore$

$>$

$>$

$\therefore$$$
\text { s }
$$ 


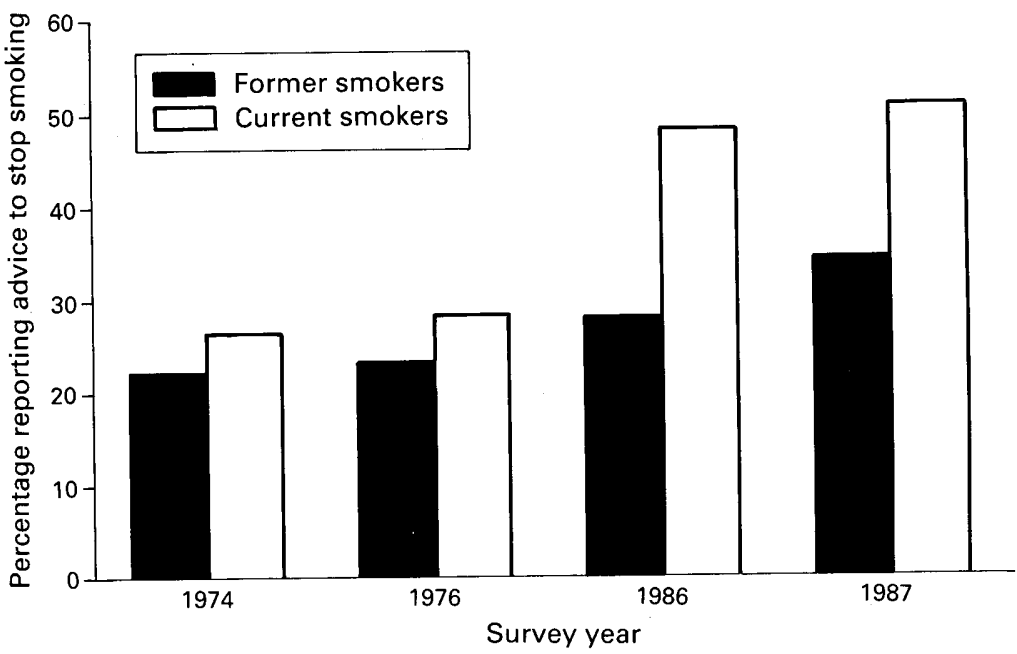

Figure 1 Rate of reported advice for current and former smokers by survey year. The increase is significant for both current and former smokers $\left(p<10^{-8}\right)$

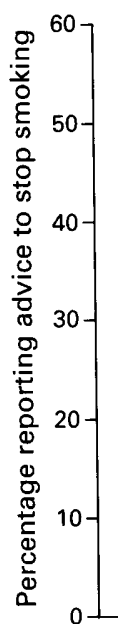

Figure 2 Rate of reported advice for former smokers by time since smoked and for current smokers in the 1986 and 1987 surveys $\left(p<10^{-8}\right)$

Percentages of current smokers advised to stop smoking by time period and demographic characteristics. Standard errors are given in parentheses

\begin{tabular}{|c|c|c|c|}
\hline $\begin{array}{l}\text { Demographic } \\
\text { characteristic }\end{array}$ & $\begin{array}{l}1974-6 \\
(n=16033)\end{array}$ & $\begin{array}{l}1986-7 \\
(n=10403)\end{array}$ & $\begin{array}{l}\text { Crude } \\
\text { ratio }\end{array}$ \\
\hline Overall & $27 \cdot 3(0 \cdot 4)$ & $49.7(0.5)$ & $1 \cdot 8)$ \\
\hline \multicolumn{4}{|l|}{ Sex: } \\
\hline $\begin{array}{l}\text { Men } \\
\text { Women }\end{array}$ & $\begin{array}{l}25.8(0.5) \\
28.9(0.5)\end{array}$ & $\begin{array}{l}45 \cdot 8(0.7) \\
53.3(0.7)\end{array}$ & $\begin{array}{l}1.8 \\
1.8\end{array}$ \\
\hline \multicolumn{4}{|l|}{ Age (years): } \\
\hline $20-29$ & $19 \cdot 4(0 \cdot 7)$ & $41.9(1.1)$ & $2 \cdot 2$ \\
\hline $30-44$ & $26.7(0.6)$ & $49.6(0.8)$ & 1.9 \\
\hline $45-64$ & $33.0(0.9)$ & $55 \cdot 1(1 \cdot 1)$ & $1 \cdot 7$ \\
\hline$\geqslant 65$ & $33.4(1.2)$ & $54.5(1.4)$ & 1.6 \\
\hline \multicolumn{4}{|l|}{ Race: } \\
\hline White & $28.5(0.4)$ & $51.5(0.5)$ & 1.8 \\
\hline Black & $18.4(0.9)$ & $39.4(1.3)$ & $2 \cdot 1$ \\
\hline Other & $15.9(3 \cdot 1)$ & $44 \cdot 1(3 \cdot 0)$ & $2 \cdot 8$ \\
\hline \multicolumn{4}{|l|}{ Education (years): } \\
\hline$<12$ & $27.2(0.6)$ & $\begin{array}{l}47.9(1.0) \\
48.5(0.8)\end{array}$ & 1.8 \\
\hline 12 & $25.2(0.6)$ & $\begin{array}{l}48.5(0.8) \\
52.1(0.9)\end{array}$ & 1.9 \\
\hline $\begin{array}{l}13-15 \\
\geqslant 16\end{array}$ & $\begin{array}{l}28.5(0.6) \\
30.8(1.3)\end{array}$ & $\begin{array}{l}52.1(0.9) \\
53.4(1.5)\end{array}$ & $\begin{array}{l}1.8 \\
1.7\end{array}$ \\
\hline
\end{tabular}

and the $50 \%$ rate for 1986 to 1987 (which we are reporting here).

Our results showed several differences between demographic groups in how often they reported receiving advice to stop smoking from their physicians. Overall, percentages of those reporting they had received advice were higher for women than for men, higher for older smokers than for younger smokers, higher for white subjects than for black subjects, and higher for smokers with more than 12 years of education than for those with less education. These trends for sex and race were also found in the Michigan study. In contrast, male smokers reported being advised to stop smoking more often than did female smokers in a 1984 New York study at a family medicine outpatient centre affiliated to a university ${ }^{38}$; this difference, however, may be due to the small population size in the New York study ( $\mathrm{n}$ $=311$ ) and the small number of male smokers in that study $(n=95)$. Our study seems to show some trends for differential increases in reported rates of advice received among younger smokers and non-white subjects; however, the log linear analysis showed that these interactions with time were not significant.

A significant interaction of sex and age with time period was found. The low rate of reported advice among young men was also seen in the Michigan survey. ${ }^{36}$ Young men may receive the least advice because they visit a physician less frequently than do older men or women of all ages. Women aged 20 to 29 years were advised 2.3 times more in the later time period, possibly because of increased awareness of the risks of smoking to unborn babies and to women who take birth control pills. White subjects were advised more often than black subjects in both time periods; this result could be due either to black subjects receiving less advice than white subjects or to black subjects making few visits than white subjects to physicians. Older people reported being advised to stop smoking more often than did younger people. This finding may be a result of more visits to the doctor by older people or a demographic aging of the population, or both. ${ }^{39}$

In 1986 and $1987,50 \%$ of all current smokers reported having been advised to stop smoking by a physician. In the New York study $68 \%$ of the patients said that they would try to stop smoking if their physicians advised them to do so; however, only $41 \%$ of the patients in that study reported having been given advice to stop by the resident physician who saw them at the centre. ${ }^{38}$ In seven studies that relied on self reports by physicians (including two national surveys of family practitioners) the percentage of doctors reporting that they regularly advised their patients who smoked to stop ranged from $52 \%$ to $97 \%{ }^{20-27}$

Several factors may account for the discrepancy in the advice rates reported by patients and physicians. Firstly, physicians who do not respond to voluntary surveys about how often they advise patients to stop smoking may be the physicians who do not routinely give such advice. Secondly, the types of physicians seen most often by smokers may not be specialists in cardiopulmonary medicine, may not be as aware of the importance of advising patients to stop smoking, and therefore may not advise their patients as often. ${ }^{23}$ Thirdly, physicians may be more likely to 


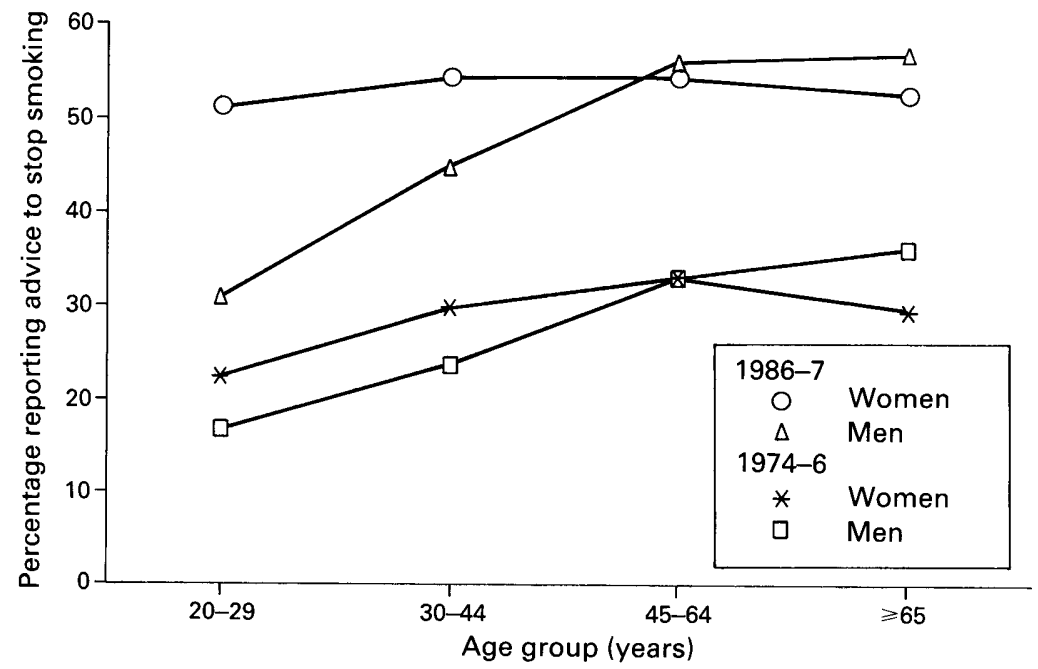

Figure 3 Rate of reported advice showing differences in pattern by sex, age, and time period cians perceive that such advice has much less impact than standard treatments for other ailments. Physicians need to understand that the success of their efforts is not measured in how many patients become secure ex-smokers in the year after the advice was given; on this scale a stopping rate of something less than $10 \%$ is to be expected. ${ }^{3845}$ Rather, physicians should realise that their advice will lead the patient along the normally circuitous path to stop smoking: smokers generally cycle through stages of not thinking about stopping, thinking about it, and making an attempt followed by relapse and another period of disinterest. ${ }^{46}$ However, repeated advice to stop smoking plus similar messages from other sources will help the process along so that at some point the smoker will make the attempt that succeeds and become one of the successful former smokers.

Also, more physicians might take an active role if $(a)$ they were adequately trained and financially reimbursed and $(b)$ the climate for priorities in time, space, and for preventive rather than curative approaches to disease could be established. ${ }^{47}$ Thus advocacy groups must increase their efforts to reach physicians and to provide them with the information, the materials, and the confidence to assume an assertive role in the protection of this area of their patients' health. Recently the American Medical Association launched a new initiative to encourage and assist physicians to help their patients stop smoking recommending a physician delivered message "at every available opportunity." 48

One limitation of our study is that we do not know how long before the survey the respondents received the advice to stop smoking. Another limitation is that we do not know to what extent individual demographic subgroups report receiving more or less advice because they visit a physician more or less frequently than people in other subgroups. Further surveys to assess more fully the current extent of reported physicians' advice to stop smoking are needed to overcome these limitations.

This study was supported by grant number NO1-CN-95182 from the National Cancer Institute to ROW Sciences under a subcontract to the University of California Cancer Center and grant number IRT 245 from the Tobacco-Related Disease Research Program to the Cancer Center at the University of California, San Diego. We thank Elizabeth Whalen, Ruth Amaral, and Monica Robinson for their expert editorial assistance in preparing the manuscript.

1 US Department of Health and Human Services. Reducing the health consequences of smoking : 25 years of progress. A report of the Surgeon General. Rockville, Maryland: US Department of Health and Human Services, 1989. DHSS publication (CDC) 89-8411.)

2 Royal College of Physicians of London. Smoking and health. Summary and report of the Royal College of Physicians of other diseases. New York: Pitman, 1962.

Pierce JP, Fiore MC, Novotny TE, Hatziandreu EJ, Davis RM. Trends in cigarette smoking in the United States. $\mathscr{T} A M A 1989 ; 261: 56-60$.

4 Centers for Disease Control. The heath benefits of smoking cessation: a report of the Surgeon General, 1990. Rockville, cessation: a report of the Surgeon General, 1990. Rockville, Maryland: US Department of Health and Human Services, 1990 . (DHHS publication (CDC) $90-8416$.)
Promoting health/preventing disease: year 2000 objectives for

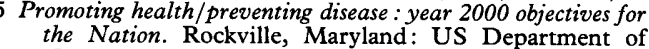
Health and Human Services, 1989. tacts) ${ }^{1745}$ Although the number of smokers smoking in recent years is physicians to stop to 20 years ago, many smokers still are not being reached by this important form of intervention. Physicians may hesitate to advise patients to stop smoking because the physi- 
6 Donovan JW. Randomized controlled trial of anti-smoking advice in pregnancy. Br f Prev Soc Med 1977;31:6-12.

7 Hjermann I, Velve Byre K, Holme I, Leren P. Effect of diet and smoking intervention in the incidence of coronary heart disease. Report from the Oslo Study Group of a randomized trial in healthy men. Lancet 1981;ii:1303-10.

8 Rosser WW. The role of the family physician in smoking cessation. Canadian Family Physician 1984;30:160-8.

9 Canadian Task Force on the Periodic Health Examination: The periodic health examination. Can Med Assoc 7 $1979 ; 121: 1193-254$.

10 Gritz ER. Cigarette smoking: the need for action by health professionals. $C A 1988 ; 38$ : $195-211$

11 Kottke TE, Battista RN, Di Friese GH, Brekke ML. Attributes of successful smoking cessation interventions in medical practice. $\mathcal{F} A M A 1988 ; 259: 2883-9$.

12 Rose G, Hamilton PSS. A randomized controlled trial of the effect on middle-aged men of advice to stop smoking. f Epidemiol Community Health 1978;32:275-81.

13 Stewart PJ, Rosser WW. The impact of routine advice on smoking cessation from family physicians. Can Med Assoc $71982 ; 126: 1051-4$

14 Russell MAH, Wilson C, Taylor C, Baker CD. Effects of general practitioners' advice against smoking. $B M \mathcal{Y}$ general practition

15 Jamrozik K, Vessey M, Fowler G, Wald N, Parker G Vunakis $\mathrm{H}$. Controlled trial of three different antismoking Vunakis H. Controlled trial of three different antismoking
interventions in general practice. $B M \mathcal{F} 1984 ; 288: 1499-$ interven

16 Wilson DM, Taylor W, Gilbert JR, Best JA, Lindsay EA, Wilms DG, et al. A randomized trial of a family physician intervention for smoking cessation. $\mathscr{\jmath} A M A$ $1988 ; 260: 1570-4$.

17 Kottke TE, Brekke ML, Solberg LI, Hughes JR. A randomized trial to increase smoking intervention by physicians: doctors helping smoker, round 1. fAMA $1989 ; 261: 2101-6$.

18 Cohen SJ, Stookey GK, Katz BP, Drook CA, Smith DM. Encouraging primary care physicians to help smokers quit. Ann Intern Med 1989;110:648-52.

19 Glynn TJ, Manley MW, Pechacek TF. Physician-initiated smoking cessation program: the National Cancer In-
stitute Trials. In: Advances in cancer control : screening stitute Trials. In: Advances in cancer control. screen

20 Wechsler H, Levin S, Idelson RK, Rothman M, Taylor JD. The physician's role in health promotion - a survey of primary care practitioners. $N$ Engl $f$ Med 1983;308:97-100

21 Orleans CT, George LK, Houpt JL, Brodie KH. Health promotion in primary care: a survey of US family practitioners. Prev Med 1985;14:636-47.

22 Rimer BK, Strecher VJ, Keintz MK, Engstrom PF. Short report: a survey of physicians' views and practices of patient education for smoking cessation. Prev Med $1986 ; 15: 92-8$.

23 Wells KB, Lewis CE, Leake B, Schleiter MK, Brook RH. The practices of general and subspecialty internists in counseling about smoking and exercise. Am $f$ Public Health 1986;76:1009-13.

24 Fortman SP, Sallis JF, Magnus PM, Farquhar JW. Attitudes and practices of physicians regarding hyper-
tension and smoking: the Stanford Five City Project. tension and smoking: the

25 Ockene JK, Williams J, Hosmer D, Goldberg RJ, Raia TJ. A survey of physicians smoking intervention practices. Proceedings of the annual meeting of the Society for Behavioral Medicine, March 1986, San Francisco, California.

26 Rosen MA, Logsdon DN, Demak MM. Prevention and health promotion in primary care: baseline results on physicians from the Insure project on lifecycle preventive health services. Prev Med 1984;13:535-48.

27 Valente CM, Sobal J, Muncie HL, Levine DM, Antlitz AM. Health promotion: physicians' beliefs, attitudes and practices. Am $\mathcal{F}$ Prev Med 1986;2:82-8.
28 The National Health Interview Survey design, 1973-84, and procedures 1975-1983. Hyattsville, Maryland: US Department of Health and Human Services, 1985. (DHHS publication (PHS) 85-1320.)

29 Current estimates from the Health Interview Survey. US Department of Health, Education, and Welfare, 1987. (Series 10, No 166.)

30 Tobacco Use in 1986: methods and basic tabulations from adult use of tobacco survey. Atlanta, Georgia: Centers for Disease Control, Office on Smoking and Health, 1989. (US Government Printing Office publication 89-625512: 10491.)

31 Fiore MC, Novotny TE, Pierce JP, Giovino GA, Hatziandreu EJ, Newcomb PA, et al. Methods used to quit 32 EPISTAT (software). Richardson, Texas: Epistat Services, 1987.

33 SPSS-X user's guide, 3rd ed. Chicago, Illinois: SPSS, 1988:536-68.

34 US Department of Health, Education, and Welfare. Use of tobacco: practices, attitudes, knowledge, and beliefs, United States - Fall 1964 and Spring 1966. US Department of Health, Education, and Welfare, Public Health Service, Health Services and Mental Health Administration, National Clearinghouse for Smoking and Health, 1969.

35 US Department of Health, Education, and Welfare. Adult use of tobacco, 1970. US Department of Health, Education, and Welfare, Public Health Service, Health Services and Mental Health Administration, National Clearinghouse for Smoking and Health, 1973.

36 Anda RF, Remington PL, Sienko DG, Davis RM. Are physicians advising smokers to quit? $\mathcal{J} A M A$ $1987 ; 257: 1916-9$.

37 US Dept of Health, Education, and Welfare. Adult use of tobacco, 1975. US Department of Health, Education, and Welfare, Public Health Service, Health Services and Mental Health Administration, National Clearinghouse for Smoking and Health, 1976.

38 Cummings $K M$, Giovino G, Sciandra R, Koenigsberg $M$, Emont SL. Physician advice to quit smoking: who gets it and who doesn't. Am 7 Prev Med 1987;3:69-74.

39 Health United States 1986 and prevention profile. Hyattsville, Maryland: US Department of Health and Human Services, 1986. (DHHS publication (PHS) 87-1232.)

40 Ockene JK, Hosmer DW, Williams JW, Goldberg RJ, Ockene IS, Dalen JE. The relationship of patient Ockene 1S, Dalen JE. The relationship of patient characteristics to physician delivered smo

41 Fordham D, McPhee SJ, Bird JA, Rodnick JE, Detmer WM. The Cancer Prevention Reminder System. $M D$ Computing 1990;7:289-95.

42 Stretcher VJ, O'Malley MS, Villagra VG, Campbell EE, Gonzalez JJ, Irons TG, et al. Can residents be trained to counsel patients about quitting smoking? Results from a randomized trial. 7 Gen Intern Med $1991: 6: 9-17$.

43 Schwartz JL. Review and evaluation of smoking cessation methods: the United States and Canada, 1978-1985.

Bethesda, Maryland: National Cancer Institute, 1987. (NIH publication 87-2940.)

44 Guidelines to clinic preventative services : an assessment of the effectiveness of 169 interventions. Report of the US Preventive Services Task Force. Baltimore, Maryland: Preventive Services Task Force.
Williams and Wilkins, 1989.

45 Fordham D, McPhee SJ, Bird JA, Rodnick JE, Detmer WM. The cancer prevention reminder system. $M D$ Computing 1990; 7:289-95.

46 Prochaska JO, DiClemente CC. Stages and processes of self-change of smoking: toward an integrative model of change. F Consult Clin Psychol 1983;51:390-5.

47 Orlandi MA. Promoting health and preventing disease in health care settings: an analysis of barriers. Prev Med $1987 ; 16: 119-30$

48 American Medical Association. The AMA challenges America's physicians to ... stop one of America's leading killers. F $A M A 1991 ; 266: 3219-24$. 


\section{Translations}

of abstract
Evolution du nombre de médecins qui recommandent à leurs patients d'arrêter de fumer, Etats-Unis, 1974-87

Elizabeth Gilpin et al

\section{Résumé}

Objectif: Evaluer la fréquence avec laquelle, entre 1974 et 1987, les patients déclarent que leur médecin leur a recommandé d'arrêter de fumer et identifier des variations parmi les sous-groupes démographiques. Contenu: Analyse des facteurs démographiques et du nombre de fumeurs de longue date déclarant avoir reçu des conseils pour arrêter de fumer. Ces derniers ont été identifiés lors d'enquêtes sur la santé, effectuées par sondages nationaux en 1974, 1976 et 1987 et de l'enquête sur l'usage du tabac parmi les adultes en 1986. Contexte: Etudes portant sur une large population: Etats-Unis.

Sujets: 40466 sujets âgés de plus de 20 ans qui ont déjà fumé 100 cigarettes dans leur vie.

Base d'évaluation: La probabilité pour un fumeur de longue date de devenir non fumeur après avoir reçu des conseils pour arrêter de fumer en 1974-76 et en 1986-87 en fonction de l'âge, du sexe, de la race et de l'éducation. Résultats: Le pourcentage de fumeurs déclarant avoir reçu des conseils est passé de $26.4 \%$ en 1974 à $50.9 \%$ en 1987. Le nombre de personnes déclarant avoir reçu des conseils était 1,8 fois supérieur en 1986-87 par rapport à la période 1974-76. Au cours de ces deux périodes, la probabilité d'avoir reçu des conseils d'un médecin était supérieure pour les femmes, les personnes âgées, les personnes benéficiant d'un meilleur niveau d'éducation, et les personnes de race blanche. Au cours de ces mêmes périodes le nombre d'hommes jeunes déclarant avoir reçu des conseils les avisant d'arrêter de fumer était inférieur à celui d'hommes plus âgés ou de femmes de tous âges. En 1987 cependant, la moitié des fumeurs réguliers ne se rappelle pas qu'un médecin leur ait conseillé d'arrêter de fumer.

Conclusion: Puisque les conseils du médecin pour arrêter de fumer sont efficaces, les médecins doivent suivre l'appel de l'American Medical Association qui leur demande de systématiquement recommander à leurs patients d'arrêter de fumer.
Tendencias en cuanto a médicos que dan asesoramiento para dejar de fumar, Estados Unidos, 1974-87

Elizabeth Gilpin et al

\section{Resumen}

Objetivo: Calcular la tasa de notificación de los pacientes que han recibido asesoramiento de un médico para cesación de tabaquismo desde 1974 a 1987, e identificar diferencias entre los subgrupos demográficos.

Diseño: Análisis de los factores demográficos y de los casos notificados de asesoramiento para dejar de fumar en personas que fumaron alguna vez, identificadas en las encuestas nacionales de salud realizadas por entrevistas en 1974, 1976 y 1987 y en la encuesta de 1986 sobre tabaquismo entre adultos.

Entorno: Encuestas en grupos grandes de problación. Estados Unidos.

Sujetos: 40,466 sujetos de más de 20 años que habían fumado por lo menos 100 cigarrillos en su vida.

Principales resultados: La probabilidad de que una persona que hubiere fumado alguna vez en su vida, notificara haber recibido asesoría para dejar de fumar en 1974-6 y 1986-7 por edad, sexo, raza y nivel de educación.

Resultados: El porcentaje de fumadores que notificaron haber recibido asesoría aumentó de un $26,4 \%$ en 1974 a un $50,9 \%$ en 1987 . La tasa notificada de haber recibido asesoramiento fue 18 veces mayor en 1986-7 comparada con 1974-6. En ambos perídos la probabilidad de que alguien notificara haber recibido asesoría médica era más alta para las mujeres, las personas mayores, las más instruidas y para los blancos. En ambos periodos los hombres jóvenes notificaron haber recibido asesoramiento para dejar de fumar a una tasa mucho más baja que la correspondiente a hombres de más edad o a mujeres de cualquier edad. Sin embargo, la mitad de todos los fumadores actuales en 1987 no podía recordar haber recibido asesoría médica para dejar de fumar.

Conclusión: Puesto que el asesoramiento de los médicos para dejar de fumar es eficaz, estos profesionales deben atender el llamado reciente de la Asociación Médica de Estado Unidos (AMA) que recomienda aconsejar a todos los pacientes que dejen de fumar cada vez que tengan contacto con ellos.

\section{医生劝烟民戒烟的趋势（美国: $1974 ＼mathrm{~ 1987 ） ~}$ 伊丽蛅白・吉尔品等}

目标: 评估病人据告接受医生成烟好告的比率，并分析此比率在不同人群中是否存在差开， 设计：调查吸烟者的人口统计因素及报告接受成烟劝告的比高，研究人群为在 1974、1976 和 1987 年三次全国集康调查及 1986 年成人烟草使用调查中确定为吸烟者的人。

研究人群: 美国大规模调查的人群.

对家: 20 岁以上, 至少曾吸过 100 支卷烟的人 40.466 名.

主夏指标：在 $1974 \sim 76$ 年和1 $1986 \sim 87$ 年两段时间内，不同年蛉、性别、民和文化程度

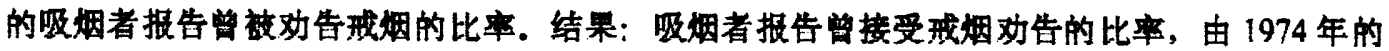
$26.4 \%$ 提高到 1987 年的 $50.9 \%$. 与 $1974 \sim 76$ 年相比，1986 87 年接受戒姻劝告的比束提高 了 1.8 倍. 在这两段时间里, 女性、老年人、文化程度高的人和白人报告接受医生戒烟劝告 的比率最高，而年轻人接受劝告的比率远远低于较年长的男性和所有女性的比率。根据 1987 年统计数字, 有一半吸烟者已不记得医生曾劝告他们找烟.

结论: 医生对吸烟者的戒烟好告是有效的, 因此医生一定要哬应美国医学会的号石, 每次都 要劝所有的吸烟病人戒姻. 